\title{
Olhares complementares sobre letramento científico e o papel dos pesquisadores em comunidades virtuais
}

\author{
Rodrigo Silva Caxias de Sousa \\ Universidade Federal do Rio Grande do Sul (UFRGS), Porto Alegre, RS, Brasil; \\ rodrigo.caxias@ufrgs.br \\ Leilah Santiago Bufrem \\ Universidade Federal de Pernambuco (UFPE), Recife, PE, Brasil; \\ santiagobufrem@gmail.com \\ Bruna S. do Nascimento \\ Universidade Federal do Estado do Rio de Janeiro (UNIRIO), Rio de Janeiro, RJ, Brasil; \\ brusnascimento@gmail.com
}

\begin{abstract}
Resumo: Este é um estudo webométrico sobre a discussão em torno das audiências a serem privilegiadas no que tange aos impactos e à incidência das informações de caráter científico. A pesquisa verifica de que maneira e com qual intensidade essas modificações no fluxo informacional ocorrem no ambiente virtual. Para tanto, realiza-se um levantamento de quatro blogs identificados no Anel de Blogs ABC: Um Longo Argumento, Via Gene, Cultura Científica e Neurocientista de Plantão. O estudo utiliza o software SocSciBot4 (Thewall, 2013) na categorização das postagens realizadas pelos pesquisadores responsáveis no período entre janeiro e dezembro de 2012 . O estudo ainda afirma que a possibilidade de novas formas de letramento científico é concretizada na web e infere que, sob esse viés, é prudente observar o quanto uma nova forma de comunalismo vem se manifestando na rede no sentido de viabilizar estratégias de letramento científico.
\end{abstract}

Palavras-chave: Comunicação Científica. Webometria. Letramento Científico. Blogs. Pesquisadores Brasileiros.

\section{Introdução}

O circuito de produção do conhecimento científico tem como característica imperante a socialização dos resultados oriundos da pesquisa científica junto à sociedade. A característica mencionada implica também que os públicos produto- 
res de informação comportem-se de forma condizente com os ditames institucionalizados em relação às comunidades científicas às quais pertençam. $\mathrm{O}$ respeito a essa premissa se traduz em formas específicas de compartilhamento de informações, auxiliando a compor um imaginário acerca do papel do cientista na sociedade.

Se tomarmos como base as contribuições de Robert K. Merton (1970), a produção científica só teria sentido se seus produtores respeitassem a máxima de que a comunicação científica é o propósito maior que permite à Ciência se reproduzir indefinidamente, alimentando um sistema cíclico, ininterrupto e cumulativo (ZIMAN, 1976). Um olhar desavisado sobre o fenômeno pode tranquilamente resumir a complexidade dos meandros, dispositivos e processos que compõem a Ciência, tal como ocorre quando se desconsideram as implicações que o uso dos blogs vem acarretando aos processos de divulgação, disseminação e comunicação científica.

O blog, adotado como meio de comunicação, vem sendo incorporado em diferentes instâncias da comunidade científica da mesma forma que é utilizado por leigos, por jornalistas científicos, pelos grandes conglomerados de comunicação e por instituições científicas. Ao buscar compreender tais vicissitudes, defendemos que as plataformas de serviço web 2.0 permitiram uma maior amplitude em relação ao alcance que passam a ter as informações relacionadas ao campo científico. A nova arena de diálogos construída pela web 2.0 recompôs a teia social estruturada das intervenções possíveis entre os agentes, permitindo que fossem engendradas alternativas de socialização de informações de tal maneira a unir pontos equidistantes, desnaturalizando a clivagem entre o cientista e o cidadão comum.

Nesse novo ambiente, é ainda mais visível a possibilidade de se estabelecer diálogo com o campo científico, por meio da recodificação da linguagem, objetivando abranger e contatar o público leigo. Com o intuito de reconhecer e descrever as práticas constituintes desse espaço, é necessário apontar para fenômenos que ocorrem concomitantemente à agilização e divulgação dos resultados de pesquisa. Isso por que a web 2.0 permite a composição de serviços e produtos calcados em alterações tecnológicas que viabilizam a estruturação de redes soci- 
ais. Ademais, esses fenômenos também estão relacionados às alterações no comportamento dos produtores e consumidores de informação no que concerne à Ciência, de tal forma que seus papéis, como autores, editores, leitores e divulgadores, vêm sendo redimensionados e visualizados em manifestações como os blogs.

Nos blogs, as menções a resultados anteriores de pesquisa não podem ser entendidas como um tipo de convenção a ser respeitada pelos seus autores. Isso porque podemos encontrar citações e referências entre as postagens, ou links, que não remetem o leitor a fontes ou documentos que abordam informações limítrofes e/ou inscritas ao universo científico. É sobre essas produções e possibilidades, a partir das quais os pesquisadores passam a cumprir papéis que não se configuram como suas atribuições tradicionais, que se estabeleceu o seguinte problema de pesquisa: os blogs de pesquisadores são utilizados como arenas discursivas para a prática do letramento científico?

\section{Alfabetização e letramento científico: etapas de um processo emancipató- rio}

Destacar o papel da alfabetização científica, como indispensável ao processo de letramento científico é de suma importância para a correta compreensão das novas práticas políticas e sociais ensejadas pela web 2.0. Nesse novo ambiente interativo, é possível articular opiniões, pensamentos, conceitos e conteúdos (acadêmicos ou não) acerca de qualquer tema e obter, muitas vezes quase instantaneamente, a réplica sobre a postagem publicada. O uso da escrita para publicizar informações no contexto das comunidades virtuais e a interação dialógica estabelecida, por meio dos comentários, entre indivíduos, é o que define o sentido atribuído nessa pesquisa ao letramento científico. Ele se vale dos conhecimentos prévios e imprescindíveis adquiridos no processo de alfabetização científica. Nessa etapa de aprendizagem, a analogia com a alfabetização, entendida aqui no seu sentido estrito de um tipo de prática educativa, prevê que o indivíduo adquira domínio sobre determinados códigos que lhe permitam utilizar tanto a escrita quanto a leitura para informar e informar-se. A importância e comple- 
xidade desse domínio do código explica a razão porque a leitura constitui um campo de investigação intensiva, associado à procura da compreensão científica desse tipo de aprendizagem (FRANCHI, 1989).

No que concerne ao letramento científico, o agente - seja ele leigo ou especialista - é considerado apto quando é capaz de compreender textos sobre Ciência escritos nos mais variados suportes, dentre eles o virtual, aqui representado pelas postagens analisadas nos blogs. Esse processo de letramento prevê a aquisição de habilidades (teóricas e tecnológicas) que permitam a contextualização política, conceitual e ideológica dos conteúdos disponibilizados, visando atingir determinados objetivos. Paulo Freire (1967), apontou que as práticas de leitura e escrita deveriam extrapolar o plano individual da aprendizagem e ser vivenciadas no uso social e consciente dessas interações. Mesmo não abordando explicitamente o termo atual de letramento, o educador sintetizou o que hoje pode ser creditado a esse processo, considerado por ele

[...] mais do que o simples domínio psicológico e mecânico de técnicas de escrever e de ler. É o domínio dessas técnicas, em termos conscientes. É entender o que se lê e escrever o que se entende. É comunicar-se graficamente. É uma incorporação. Implica, não uma memorização visual e mecânica de sentenças, de palavras, de sílabas, desgarradas de um universo existencial - coisas mortas ou semimortas - mas numa atitude de criação e recriação. Implica numa auto formação de que possa resultar uma postura interferente do homem sobre seu contexto. (FREIRE, 1967, p. 117, grifo nosso).

É esse conjunto de contextos, de apropriações e de interações que delimita o processo de letramento científico. Defendemos aqui a ideia de que ele não se finda, uma vez que novas realidades se impõem periodicamente em todos os campos científicos - pois não se faz Ciência descolada da situação política, ideológica e econômica vigente. Segundo Ziman (1979, p. 26), “[...] a Ciência é pública, e, portanto moldada e determinada pelas relações sociais entre indivíduos.”. São essas relações que conferem ao processo de letramento científico seu caráter coletivo. Enquanto a prática de alfabetização se dá por meio do aprendizado individualizado e mediado pela figura professoral, o letramento tem por característica principal a interação, ou melhor, as trocas estabelecidas entre indivíduos e o campo (seja ele social, político ou científico). Para Mamede e 
Zimmerman, "[...] a alfabetização refere-se às habilidades e conhecimentos que constituem a leitura e a escrita, no plano individual, ao passo que o termo letramento refere-se às práticas efetivas de leitura e escrita no plano social." (2007, p. 1). Concordamos com o exposto pelos referidos autores, ampliando essas concepções ao plano específico da Ciência, na medida em que se compreende a alfabetização e o letramento científico como etapas de um processo civilizatório maior. Santos (2002) corrobora a vital importância conferida à prática e aos processos supramencionados quando afirma que somente com a aquisição dessas competências será conferido aos indivíduos o pleno exercício de sua cidadania, isso tendo em vista os desafios propostos e impostos pela nova configuração social e tecnológica do mundo.

No caso específico dos $b \log s$, tanto as postagens quanto os direcionamentos hipertextuais, compostos a partir dos links, indicam intencionalidades no que se refere à proposição de uma arena discursiva, na qual a interação entre esses pesquisadores e as diferentes audiências mobilizadas se configure como uma estratégia de letramento científico. Nesse sentido, práticas de divulgação, de disseminação e de comunicação científica viabilizam a constituição dos blogs de pesquisadores e ao mesmo tempo são resignificadas pela participação, por meio dos comentários, dos agentes envolvidos. É nesse espaço discursivo que o letramento científico se faz possível mediante a internalização e exteriorização dos conteúdos publicados. Para compreender de forma mais clara as diferenças e as proximidades dessas práticas comunicativas, é imprescindível que se definam os seguintes termos: divulgação, disseminação e comunicação científica, pois eles apresentam diversas conceituações na literatura corrente.

\section{Divulgação, disseminação e comunicação científica: em busca de um con- senso teórico}

O que se pôde observar com o surgimento da web 2.0 foram pequenas e significativas alterações nos processos comunicativos da Ciência. Neles estão contempladas a divulgação, a disseminação e a comunicação científica, pois todas sofreram modificações no seu "fazer". Ainda segundo os autores, há uma tendên- 
cia de abordar o tema sob a perspectiva seccionada dos produtores e dos consumidores de informação científica. Entretanto, com a web 2.0, a distinção dos papéis desempenhados por esses dois agentes já não é mais possível, visto que ora ele pode ser consumidor, ora produtor de conteúdo.

O espaço em que reverberam informações e diálogos relativos à Ciência está sendo alterado não por disposições hereditárias ou rupturas grandiosas de paradigmas, mas pelas modificações advindas da nova configuração da web. Com esse novo espaço, o papel desempenhado pelo pesquisador adquiriu novos contornos, ensejando novas atuações frente à comunidade, seja ela acadêmica ou leiga. Nesse momento, se fazem necessárias a conceituação e a delimitação das funções desempenhadas pela divulgação, disseminação e comunicação científi$\mathrm{ca}^{1}$.

Bueno $(1984,2010)$ trabalha nesse sentido, buscando diferenciá-las para que se tenha claro o sentido de cada uma delas e, por conseguinte, se possa otimizar o papel público e social inerente a qualquer atividade, prática ou produto científico. Acreditamos que conceituar e delimitar aproximações e diferenças relativas aos públicos, canais, discursos e intenções que cada uma delas abarca é de fundamental importância para que se compreenda o enfoque abordado na presente comunicação.

A divulgação científica propõe-se a estabelecer um elo discursivo entre a produção em Ciência e o público leigo, em geral por meio da "[...] utilização de recursos, técnicas, processos e produtos (veículos ou canais) para a veiculação de informações científicas, tecnológicas ou associadas a inovações ao público leigo." (BUENO, 2010, p. 162). O autor enfatiza que não se pode tomar a divulgação científica por sinônimo de jornalismo científico, pois há tanto uma preocupação em abranger um número maior de veículos/canais utilizados para a sua difusão - como TV, jornais, livros didáticos, histórias em quadrinhos (HQ), entre outras opções - quanto uma maior possibilidade para explorar a diversidade de formas linguísticas e estilísticas, como bem ilustram o teatro, o desenho animado e a literatura de cordel. 
Aqui se toma como sinônimos possíveis para divulgação científica os termos comunicação pública em Ciência, difusão e vulgarização científica, obviamente não no sentido de banalização, mas de popularização de conteúdo.

O conceito de comunicação pública em ciência abrange mais largamente o conjunto dos fenômenos que nos interessam. Ele engloba a soma das atividades que possuem conteúdos científicos vulgarizados e destinados ao público de não especialistas em situação não cativa. (FAYARD, 1988, p. 11-12).

Por outro lado, compreendemos que a disseminação científica tem como característica distintiva o fato de que o conteúdo das informações veiculadas não se caracteriza como resultado de pesquisa, sistematizado e avaliado pelos pares, mas pode fazer referência a tais conteúdos de maneira fracionada, tangencial ou correlacionada, utilizando a linguagem adotada pelo campo. Além disso, entendemos que a disseminação também pressupõe uma intencionalidade no que se refere ao universo de interlocutores aos quais são dirigidas as informações. Esse fato não ocorre na divulgação/difusão científica, pois se entende que nela o público a ser atingido é o geral, o leigo, sem que haja uma racionalização e um direcionamento a determinada parcela da sociedade dominante de certos códigos da linguagem científica.

Embora etimologicamente os termos divulgar, difundir e disseminar sejam tratados como sinônimos, no que concerne à prática da disseminação científica, pelo acima exposto, acreditamos que o cerne das diferenças está na delimitação do público e na utilização da linguagem.

Se nesse particular é possível distingui-las, no que se refere ao seu modo de conformação, ambas não se constituem através dos trâmites de arbitragem pelos pares, e essa característica é um dos fatores determinantes para que se proponha aqui uma terceira categoria de análise e interpretação das práticas socializadoras da Ciência: a comunicação científica. Compreendemos que a comunicação científica delimita-se aos resultados relacionados à produção de conhecimento validada por pares e veiculada em canais formais e informais, cuja principal função é: 
[...] dar continuidade ao conhecimento científico, já que possibilita a disseminação desse conhecimento a outros cientistas que podem, a partir daí, desenvolver outras pesquisas, para corroborar ou refutar os resultados de pesquisas anteriores, ou estabelecer novas perspectivas naquele campo de interesse. A comunicação científica também é capaz de definir e legitimar novas disciplinas e campos de estudos, institucionalizando o conhecimento e rompendo suas fronteiras. (GARVEY, 1979, p. 36),

Tais legitimações também ocorrem a partir da institucionalização dos mecanismos que regulam as práticas individuais dos atores envolvidos nos processos de produção e comunicação de informações científicas. Isso por que tais práticas são erigidas através da possibilidade de propiciar espaços para o letramento científico e coadunar comportamentos que respeitem os requisitos éticos compartilhados pelo conjunto organizado de pesquisadores. A possibilidade de socialização é uma das manifestações mais importantes das práticas científicas, pois ela se torna possível por meio da divulgação, da disseminação e da comunicação científica, utilizando-se de diferentes canais com diversos objetivos e direcionados a públicos também diferentes (ver Quadro 1).

Quadro 1 - Divulgação, Disseminação e Comunicação Científica: diferenças a aproximações

\begin{tabular}{|c|c|c|c|c|c|c|}
\hline \multirow[t]{2}{*}{ Categorias } & \multirow[t]{2}{*}{ Público } & \multirow[t]{2}{*}{ Objetivo } & \multicolumn{2}{|c|}{ Canais } & \multirow[t]{2}{*}{ Conteúdo } & \multirow[t]{2}{*}{ Linguagem } \\
\hline & & & Informais & Formais & & \\
\hline $\begin{array}{l}\text { Divulgação/ } \\
\text { Vulgarização/Difus } \\
\text { ão Científica, } \\
\text { Comunicação } \\
\text { Pública em Ciência }\end{array}$ & $\begin{array}{l}\text { Direcionada ao } \\
\text { público em } \\
\text { geral }\end{array}$ & $\begin{array}{l}\text { Divulgar } \\
\text { informações } \\
\text { científicas. }\end{array}$ & $\begin{array}{l}\text { TV } \\
\text { Jornais } \\
\text { Revistas } \\
\text { HQ } \\
\text { Livros } \\
\text { didáticos; } \\
\text { Museus etc. }\end{array}$ & - & $\begin{array}{l}\text { Informação } \\
\text { sistematizada e } \\
\text { não validada. }\end{array}$ & $\begin{array}{l}\text { Recodificação da } \\
\text { informação para } \\
\text { adequá-la ao } \\
\text { público leigo. }\end{array}$ \\
\hline $\begin{array}{l}\text { Disseminação } \\
\text { científica }\end{array}$ & $\begin{array}{l}\text { Direcionada a } \\
\text { um público } \\
\text { restrito }\end{array}$ & $\begin{array}{l}\text { Socializar } \\
\text { informações } \\
\text { atinentes ao campo } \\
\text { científico. }\end{array}$ & $\begin{array}{l}\text { Listas de } \\
\text { discussões; } \\
\text { Conversas em } \\
\text { grupos de } \\
\text { pesquisa; } \\
\text { e etc. }\end{array}$ & - & $\begin{array}{l}\text { Informação não } \\
\text { sistematizada e } \\
\text { nem validada } \\
\text { pela } \\
\text { comunidade } \\
\text { científica. }\end{array}$ & $\begin{array}{l}\text { Linguagem } \\
\text { codificada própria } \\
\text { do campo } \\
\text { científico ao qual } \\
\text { o texto está } \\
\text { relacionado. }\end{array}$ \\
\hline $\begin{array}{l}\text { Comunicação } \\
\text { Científica }\end{array}$ & $\begin{array}{l}\text { Direcionada a } \\
\text { um público } \\
\text { restrito }\end{array}$ & $\begin{array}{l}\text { Registrar e tornar } \\
\text { públicos resultados } \\
\text { de pesquisas; } \\
\text { Promover o } \\
\text { intercâmbio de } \\
\text { informações } \\
\text { científicas. }\end{array}$ & $\begin{array}{l}\text { Palestras, } \\
\text { conferências } \\
\text { etc. }\end{array}$ & $\begin{array}{l}\text { Periódicos } \\
\text { científicos } \\
\text { Livros }\end{array}$ & $\begin{array}{l}\text { Informação } \\
\text { sistematizada e } \\
\text { validada pela } \\
\text { comunidade } \\
\text { científica. }\end{array}$ & $\begin{array}{l}\text { Linguagem } \\
\text { codificada própria } \\
\text { do campo } \\
\text { científico ao qual } \\
\text { o texto está } \\
\text { relacionado. }\end{array}$ \\
\hline
\end{tabular}

Fonte: os autores 
A proposta da discussão aqui pautada está relacionada especificamente aos blogs pelo fato de que estes incorporam e cumprem funções relativas à proposição de um espaço para o letramento científico calcado na interação entre pesquisadores e diferentes públicos.

Targino (2000) considera que novas perspectivas devam ser trazidas à discussão acerca dos limites relacionados aos produtores e às incidências relativas aos públicos, ao defender uma ampliação das audiências, maior ênfase quanto ao papel social do pesquisador e à necessidade de sua ação transcender os limites do campo científico. Segundo a autora é impossível restringir a

[...] comunicação à mera troca de informações entre cientistas. É preciso superar a tendência da comunicação tão somente para e entre cientistas. Se a comunicação científica é básica àqueles que fazem ciência, a produção da ciência não se dá alheia ao contexto social em que se insere. Ao contrário. Como sistema social, a ciência integra elementos que vão desde a figura do pesquisador/cientista/acadêmico ao fluxo de idéias, fatos, teorias, métodos, literatura científica e instrumentos que permitem a operacionalização das investigações. Assim deve ultrapassar as fronteiras da comunidade de usuários mais imediatos, sob o risco de se tornar estéril e inútil. (TARGINO, 2000, p. 350).

$\mathrm{O}$ argumento da autora coincide com a concepção de que os pesquisadores necessitam se desvincular da perspectiva da autonomia que caracteriza a atividade científica, deixando de pressupor que seja suficiente que sua contribuição reverbere fundamentalmente no âmbito dos canais e públicos caracterizados como científicos. Essa postura requer que se repense as implicações dos processos de comunicação científica em diferentes instâncias sociais, ou seja, que se conceba a comunicação científica como atividade política nas dimensões micro, meso e macroestruturais, articulando ações institucionalizadas a movimentos originários da sociedade.

Embora as práticas de comunicação científica continuem a ser arbitradas e direcionadas aos pesquisadores a partir de canais formais e informais, por outro lado, é necessário considerar o significado do uso dos links na composição das postagens em blogs. Essas ligações denotam práticas compostas por uma variabilidade de diferentes atores, mostrando que tais manifestações devem ser 
identificadas como parte da produção informal dos pesquisadores, disponibilizada agora a partir dos serviços web 2.0. Isso por que outras racionalidades permitem identificar que os fluxos de informação engendrados a partir dos blogs têm impacto social junto à comunidade científica e ao restante da sociedade, possibilitando estratégias de letramento científico. Trata-se de um conjunto de fenômenos que começam a ser explorados. De forma explícita, Ziman (1979, p. 3) esclarece que na "[...] maioria das vezes o campo que está sendo investigado fica fora do escopo de teorias já solidamente firmadas." Sua definição de ciência

[...] implica que devem existir vastas áreas de ignorância onde o conhecimento público não tem jurisdição, isto é, onde não existem modelos de teoria e observação aprovados unanimamente. Quando começamos a explorar essas áreas, encontramos inevitavelmente muitas coisas novas. Como iremos avaliar a sua importância? Ziman (1979, p. 3).

A observação feita por Ziman (1979) nos traz indicativos acerca das limitações e dos privilégios conferidos ao estudo de certos objetos, principalmente quando observamos desdobramentos que surgem em consequência dos avanços tecnológicos e das inquietações sociais que incidem sobre a ciência e se manifestam através das plataformas web 2.0.

Especificamente em relação à citação de Ziman (1979), entendemos que seria prematuro afirmar que aos blogs se pode atribuir necessariamente o qualificador de "científicos". Porém, entendemos que interpretações sobre esses dispositivos de ligação contribuem para delinear implicações acerca dos usos em processos de comunicação propostos por pesquisadores, tendo em vista que as motivações pelas quais os links são inseridos nas postagens e as funções que cumprem reforçam o impasse sobre os limites entre as diferentes práticas comunicativas.

Os processos de divulgação científica são citados como alternativa indissociável do letramento científico dos indivíduos, por proporcionarem à população leiga maior compreensão das questões concernentes à Ciência, participando do debate público. Entretanto, o que pode ser evidenciado nos blogs é que as composições hipertextuais criadas por pesquisadores desconsideram os limites conceituais relacionados às práticas de divulgação, de disseminação e de comu- 
nicação científicas. Dessa forma, negligenciam as convenções e distinções acadêmicas convencionais verificadas nessas práticas, fato que institui uma forma anárquica de apreensão dos conteúdos nessas comunidades virtuais.

\section{A blogosfera como comunidade virtual}

A importância em problematizar questões teóricas que tangenciam as alterações proporcionadas pelo uso de plataformas de serviços web 2.0 em relação aos processos comunicativos, é necessariamente perpassada por uma série de aspectos comportamentais que desvelam o quanto os usos desses canais de informação impactam em espaços e públicos distintos.

Em relação aos blogs, é necessário pensar que sua adoção como canal que permite o acesso tanto a informações relacionadas aos resultados das pesquisas quanto à circulação de informações relativas a práticas internas das instituições científicas (debates de natureza política, peculiaridades de áreas do conhecimento, informações utilitárias) pode implicar na composição de aglomerados de indivíduos que compartilham de uma identidade coletiva, mesmo que diferentes na sua composição acadêmica. Tal identidade implicaria, a priori, num diferenciar-se em razão do discurso compartilhado, dos comentários inseridos e, por conseguinte, da arena discursiva formada pelos mais variados públicos, canais, conteúdos e linguagem utilizados.

A criação do blog constitui-se como uma relação de pertencimento e, em certa medida, torna-se uma marca que o pesquisador atribui a si mesmo. Exemplos concretos desses usos são os blogs de periódicos científicos com um alto fator de impacto, como a Science e a Nature, e de universidades, como a de Stanford, instituição que mantém um diretório com uma considerável lista de blogs de professores, alunos, gestores e grupos de pesquisa. No Brasil, isso pode ser comprovado pela inserção de um item no currículo Lattes que permite, por meio do link produção técnica, a inserção de informações sobre redes sociais, websites e blogs.

Um exemplo de iniciativa que apresenta grande popularidade em relação aos blogs de ciência registrados em domínio brasileiro é o Anel de blogs Cientí- 
ficos, conhecido na blogosfera como $\mathrm{ABC}$. A proposta do $\mathrm{ABC}$, segundo seu idealizador, é constituir um espaço que tem por objetivo principal delinear a blogosfera científica em língua portuguesa. Entretanto, é preciso questionar se empreendimentos desse tipo são realmente espaços de interlocução, compartilhamento de informações e, por fim, de letramento científico. Isso por que é necessário entender se os mesmos se constituem como espaços de socialização de informações ou se reproduzem, de forma similar, as relações de competição do campo científico.

Conceber a blogosfera como um tipo específico de comunidade virtual, sem considerar a importância do blog como meio de comunicação baseado em composições hipertextuais que permitem a bidirecionalidade entre produtores e leitores, seria uma forma de reduzir a importância de tal fenômeno. Isso por que o blog permite a inserção de dispositivos hipertextuais dos diferentes agentes, o que requer que se pense em alternativas quanto à composição de comunidades virtuais com atributos e práticas diferenciadas.

Rheingold compreende as comunidades virtuais como

[...] agregações sociais que surgem na Internet, quando um número suficiente de pessoas levam adiante discussões públicas longas e com suficiente sentimento humano, a ponto de estabelecerem redes de relacionamentos no ciberespaço. (1998, p. 5).

Concernente aos blogs, mais do que agregações, o que se coloca são possibilidades de que a blogosfera científica se constitua em espaços virtuais agregadores de múltiplos discursos, podendo ser interpretada sob pelo menos três vaiáveis: como esfera pública informal relacionada à Ciência, como uma arena discursiva na qual o habitus inerente ao campo científico é reproduzido, ou como um híbrido dessas manifestações, propiciando um espaço pertinente para o letramento científico.

$\mathrm{O}$ autor pontua acerca dos processos das transformações relacionadas ao conceito de comunidade, identificando alternativas quanto ao uso do computador como aparato técnico que medeia tipos de informação relacionados à Ciência. Nesse sentido, afirmamos que as práticas identificadas presencialmente em 
comunidades tradicionais são estendidas em razão dos espaços públicos e das oportunidades midiáticas. Se por um lado há um esfacelamento das relações e práticas comunicativas presenciais, por outro se identifica o surgimento de comunidades online, reforçando e ampliando relações que podem ou não ocorrer presencialmente.

\section{Metodologia}

Empregaram-se, neste estudo, técnicas mistas (CRESWELL, 2007) como parte de um desenho de pesquisa iniciado com um estudo exploratório dos blogs mencionados. A pesquisa foi baseada na análise de conteúdo dos links e outlinks (THELWALL, 2004) inclusos e remissivos tanto nas postagens quanto no Index dos blogs que compõem o Anel de Blogs da USP de Ribeirão Preto (ver Quadro 2).

Quadro 2-Corpus dos blogs

\begin{tabular}{|c|c|c|c|}
\hline $\begin{array}{c}\text { Blogs de Pesqui- } \\
\text { sadores }\end{array}$ & URL do Blog & $\begin{array}{c}\text { Tipo de } \\
\text { Autoria }\end{array}$ & Data da última Atualização \\
\hline $\begin{array}{c}\text { Cultura Científi- } \\
\text { ca }\end{array}$ & $\underline{\text { http://ccientifica.blogspot.com/ }}$ & Individual & $19 / 08 / 2015$ \\
\hline $\begin{array}{c}\text { Um Longo Ar- } \\
\text { gumento }\end{array}$ & $\underline{\text { http://charlesmorphy.blogspot.com/ }}$ & Individual & $31 / 05 / 2015$ \\
\hline Via Gene & $\underline{\text { http://viagene.blogspot.com/ }}$ & Individual & $05 / 05 / 2014$ \\
\hline $\begin{array}{c}\text { Neurocientista de } \\
\text { Plantão }\end{array}$ & $\underline{\text { http://www.suzanaherculanohouzel.com/ }}$ & Individual & $04 / 11 / 2014$ \\
\hline
\end{tabular}

Fonte: dados da pesquisa

Foram aplicadas técnicas webométricas para viabilizar a proposta inicial de verificar como esses quatro blogs se relacionam com o universo informacional e de que maneira utilizam essa nova arena social para o debate sobre Ciência.

Definimos a amostra de blogs tomando como base elementos característicos do blog e do pesquisador. Os critérios foram os seguintes:

a) pesquisador (es) que tenha atualizado seu blog no ano de 2014; 
b) vínculo profissional do pesquisador a uma instituição de ensino/pesquisa no Brasil.

Em um primeiro momento, verificamos como os blogs estabeleceram links com o exterior (outlinks). Para tanto, utilizamos o software SocSciBot4 (THELWALL, 2013), que permite o crawling dessas referências eletrônicas dispersas no Index dos blogs. Na presente pesquisa entendemos o link como uma fonte de informação que explicita as afiliações teórico-científicas, dentre outros aspectos possíveis de correlações feitas pelos autores.

No que concerne à análise de conteúdo, ela baseou-se nas categorias emergidas dos textos das postagens a partir da leitura flutuante (Análise de Conteúdo Dedutiva). Fragoso, Recuero e Amaral (2011) pontuam que essa técnica apresenta maior versatilidade e produtividade no que tange a análise de links, uma vez que, operando em diversas escalas de observação, esse tipo de análise “[...] permite combinar avaliação qualitativa individual dos elementos da amostra com uma sistematização quantitativa, por categorização, compatível com o volume de dados envolvidos." (FRAGOSO; RECUERO; AMARAL, 2011, p. $163)$.

As postagens foram salvas em arquivos específicos (.doc) entre os dias 10 e 12 de abril de 2013. Os dados foram organizados e nomeados separadamente em pastas do Windows com as respectivas identificações dos blogs. Foram efetuadas as leituras das postagens, buscando interpretar a inserção dos links nesses escritos com base nas categorias propostas por Sousa (2011):

a) tipo de link - baseia-se nos direcionamentos dos links segundo a proposição teórica de subcategorias obtidas dos estudos de Thelwall, Vaughan e Björneborn (2003), que são: inlink, outlink e selflink;

b) tipo de informação - relaciona-se à categoria e baseia-se no conteúdo e forma de apresentação da informação veiculada. As subcategorias propostas foram: científica, não científica e utilitária;

c) contexto de inserção-migração - Tipo de texto em que o link está inserido e para o qual remete o leitor. Nossa divisão imbrica propostas conceituais obtidas dos estudos de Wilson da Costa Bueno $(1984 ; 2010)$ e Sari- 
ta Al-bagli (1996) e divide-se em: divulgação científica, disseminação científi-ca e comunicação científica.

É importante que se reforce o conceito atribuído a cada uma dessas categorias, pois além de não haver consenso na literatura a respeito delas, há uma profusão de sinônimos a elas atribuídos de modo nem sempre correto. Por divulgação ci-entífica, também conhecida como vulgarização/difusão da ciência ou comunica-ção pública em ciência, adotamos o exposto por Bueno (2010), que a considera como a "[...] utilização de recursos, técnicas, processos e produtos (veículos ou canais) para a veiculação de informações científicas, tecnológicas ou associadas a inovações ao público leigo.” (BUENO, 2010, p.162). Ampliamos essa visão no que concerne ao discurso vinculado à prática, no qual há uma redecodificação das informações com o intuito de tornar públicas descobertas e pesquisas até então encerradas nos discursos científicos. Dentre as funções primordiais dessa modalidade discursiva, ressaltamos seu caráter democratizador, visto que objeti-va alcançar um maior número de indivíduos, extrapolando o universo restrito aos campos científicos.

A disseminação científica pressupõe, tal qual a comunicação científica, a intencionalidade no que se refere ao universo de interlocutores aos quais são dirigidas as informações, mas dela se diferencia por não cumprir com algumas prer-rogativas para a formalização do conhecimento científico, como, por exemplo, a avaliação pelos pares.

Já o termo comunicação científica está intimamente relacionado com a transferência do discurso gerado pelo e para os integrantes de determinados grupos científicos. Ele presume uma série de formatações, adequações e disposições específicas do campo científico, como, por exemplo, a avaliação pelos pares do conteúdo da informação e sua disponibilização à comunidade por meio de veícu-los autorizados da Ciência (MUELLER; PASSOS, 2000). Aqui a mensagem é elaborada a partir de códigos específicos de determinada área do conhecimento e se destina a um público também específico. Não há necessidade de concessões linguísticas que busquem uma adequação ou ampliação do universo de leitores, pois partimos da premissa de que o público-alvo compartilha e do- 
mina essa lin-guagem por meio do habitus instituído e compartilhado no campo (BOURDIEU, 2011).

\section{Análise dos dados}

A primeira parte da pesquisa permitiu, graças à utilização do software SocSciBot4 (Thelwall, 2013), que se identificassem tanto o número de páginas quanto o número de outlinks presentes nos Indexes (página inicial dos blogs) (ver Quadro 3).

Quadro 3 - Análise dos Indexes

\begin{tabular}{|l|c|c|}
\hline \multicolumn{1}{|c|}{ URL do Blog } & Páginas & Outlinks \\
\hline http://www.suzanaherculanohouzel.com/ & 3533 & 70223 \\
\hline$\underline{\text { http://viagene.blogspot.com/ }}$ & 1589 & 87919 \\
\hline http://ccientifica.blogspot.com/ & 1574 & 148363 \\
\hline http://charlesmorphy.blogspot.com/ & 2 & 1 \\
\hline TOTAL & $\mathbf{6 6 9 8}$ & $\mathbf{3 0 6 5 0 6}$ \\
\hline
\end{tabular}

Fonte: SocSciBot4 (2013)

Essa distribuição evidenciou um elevado número de outlinks no blog Cultura Científica, posteriormente corroborado pela análise de conteúdo das postagens. Isso demonstra que, em diferentes espaços do blog, as estratégias comunicativas adotadas pelo blogueiro enfatizam as hiperligações externas como um elemento que amplia as possibilidades de letramento científico, uma vez que propicia ao leitor uma multiplicidade de fontes de informação e, não raro, direciona a arenas discursivas diversas.

Ressaltamos que o pequeno número de outlinks encontrados no blog Um Longo Argumento, não significa a ausência de preocupação do pesquisador em proporcionar alternativas que permitam ao leitor ter acesso a outras informações. Embora o crawling seja efetivado a partir do Index do blog, tal fato que pode indicar uma opção do blogueiro em relação à organização da informação em seu blog tendo como alternativas outros espaços como o blogroll ou a inserção de links entre as postagens.

Foram identificados 247 links em 41 postagens relativas aos quatro blogs componentes da amostra intencional. Do total dessas 41 postagens, $9(21,95 \%)$ 
não continham links, sendo que suas ausências estão assim distribuídas (ver Quadro 4).

Quadro 4 - Ausência de links nas postagens

\begin{tabular}{|l|c|}
\hline Blogs de pesquisadores & $\begin{array}{c}\text { Número de postagens encontradas sem } \\
\text { links }\end{array}$ \\
\hline Cultura Científica & 0 \\
\hline Um Longo Argumento & 2 \\
\hline Via Gene & 2 \\
\hline Neurocientista de Plantão & 5 \\
\hline
\end{tabular}

Fonte: dados da pesquisa

Um fato significativo foi a constatação de que a postagem com maior número de comentários continha apenas um link direcionando para a tabela de bolsas e taxas do CNPQ no país e que as outras duas postagens de maior reverberação não continham sequer um link incluso. Se um grande número de links ou outlinks pode significar uma ampliação de fontes informacionais e de espaços discursivos, mas não necessariamente mobilizar a interação, um tema considerado de alta relevância pelas audiências é determinante para que o blog se concretize como um espaço de letramento científico.

Entendemos que isso só se dá mediante a interação dos partícipes não só com as temáticas abordadas, como também com a rede de interlocutores que se institui.

Cabe destacar a postagem "Você quer mesmo ser cientista" com 217 comentários. Nela é questionada a realidade brasileira no que concerne à profissão de cientista. Alguns dados, como o tempo de formação e a remuneração, são a tônica na crítica feita pela blogueira. Esse tema foi retomado em uma segunda postagem que obteve 51 comentários, ficando no terceiro lugar dentre as mais comentadas. Isso pode indicar que grande parte do público leitor e comentarista domina alguns códigos específicos do campo científico e estabelece relações entre a discussão proposta e sua própria realidade. Defendemos que esse estoque de conhecimentos se constitui por processos distintos dos observados tanto na divulgação científica quanto na comunicação científica (FAYARD, 1988; GARVEY, 1979). Nesse caso, as informações veiculadas e discutidas não circundam em torno de resultados de pesquisa, nem recodificam esses resultados em busca da ampliação da audiência. 
Continuando com a questão temática, mais especificamente em relação ao tipo de informação veiculada, a realidade observada mostrou que a imensa maioria das postagens versou sobre temas considerados científicos (ver Tabela $1)$.

Tabela 1 - Tipo de informação veiculada nas postagens (jan./dez. 2012)

\begin{tabular}{lcc}
\hline Tipo de Informação & Freq. Abs. & Freq. Rel. (\%) \\
\hline Científica & 208 & $84,21 \%$ \\
Não científica & 28 & $11,34 \%$ \\
Utilitária & 6 & $2,43 \%$ \\
Link Quebrado & 5 & $2,02 \%$ \\
TOTAL & $\mathbf{2 4 7}$ & $\mathbf{1 0 0 , 0 0 \%}$ \\
\hline
\end{tabular}

Fonte: dados da pesquisa

As incidências confirmam que independentemente das rearticulações discursivas que possam ser feitas pelos pesquisadores, eles reproduzem nos blogs as práticas que caracterizam seu ofício como produtores de conhecimento (BOURDIEU, 2011). O número reduzido de informações utilitárias indica que os pesquisadores privilegiam informações que atribuam maior popularidade aos temas científicos que desejam divulgar, disseminar e comunicar entre as comunidades virtuais.

Em relação a essas práticas comunicativas, a análise do contexto de inserção-migração mostrou-se de fundamental importância para o entendimento do blog como um espaço de letramento científico, o que corrobora as incidências anteriormente mencionadas (ver Gráfico 1). 
Gráfico 1 - Contexto de inserção-migração das postagens (jan./dez. 2012)

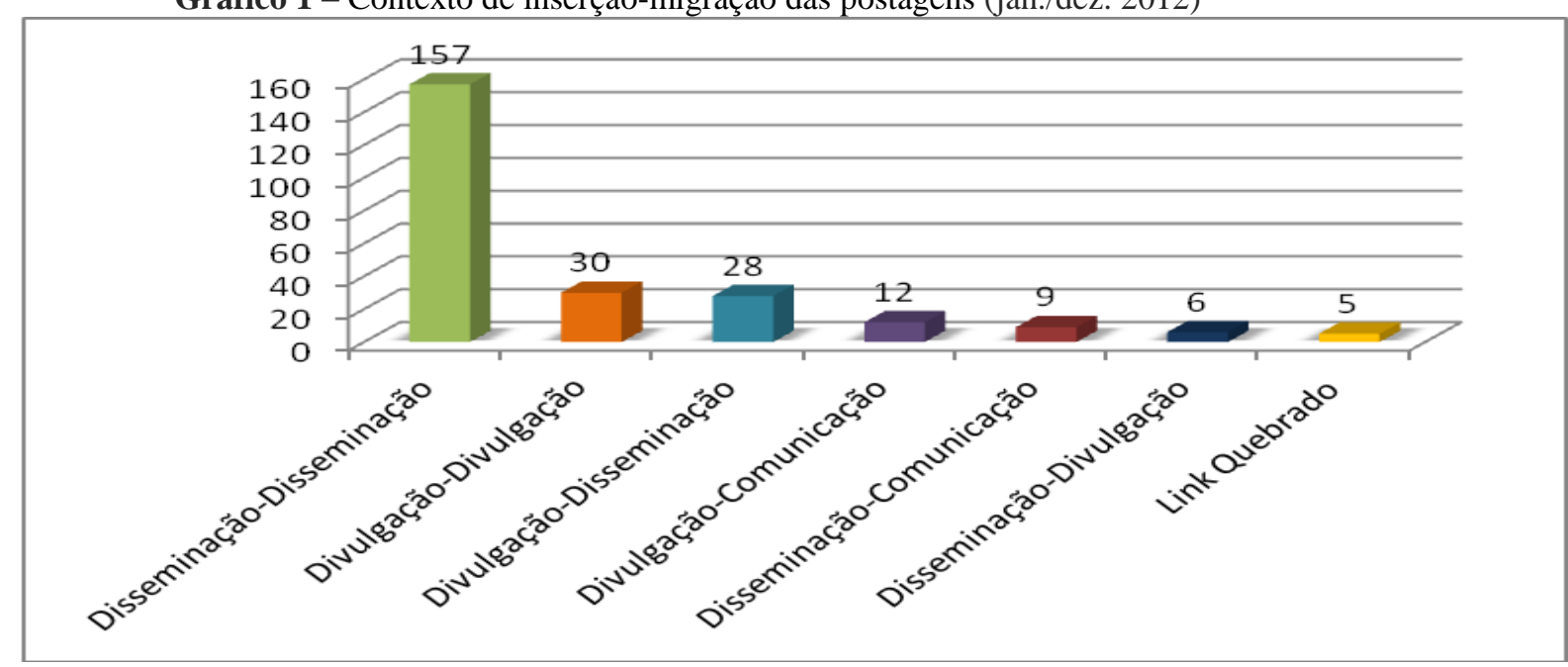

Fonte: dados da pesquisa

Defendemos que a prática de disseminação científica se constitui pela disponibilização de informações atinentes ao campo científico, sem tratar-se da apresentação de resultados de pesquisa sistematizados e avaliados e sem recodificação linguística objetivando atingir o público leigo. Por essa razão, não foi surpresa encontrar a predominância de contextos de inserção-migração movimentando-se em ambos os sentidos.

As análises dos dados até aqui efetivadas emergiram das categorias mencionadas, procurando configurar, a partir das incidências, as opções de links na composição das mensagens, a tipologia de informações propostas e o contexto de origem e destino para o qual as informações migravam segundo uma abordagem analítica de caráter conceitual. Nos espaços de escrita a seguir, pontuamos acerca das formas de composição dos blogs que denotam elementos constituintes do habitus dos pesquisadores.

O comportamento adotado pelo pesquisador que compõe as postagens do blog Cultura Científica tem como principal característica o uso de outlinks nas postagens, direcionando o leitor a fontes de informação externas. Neste blog, o autor opta fundamentalmente por composições que busquem desmitificar questões relativas à Ciência, proporcionando a interlocução de iniciados nas temáticas científicas com vistas à composição de processos de letramento científico. A mesma máxima pode ser ampliada à totalidade da amostra intencional. 
No blog A Neurocientista de Plantão as postagens integrantes do corpus da pesquisa foram escritas e direcionadas tendo como perspectiva a disseminação científica, pois $97,73 \%$ das postagens, no que se refere ao contexto de inserção-migração, mobilizaram essa prática comunicativa. Tal análise se deu em razão de o conteúdo e, por conseguinte, o direcionamento das mensagens estar explicitamente vinculado a públicos específicos.

O blog Um Longo Argumento caracterizou-se, como todos os analisados, por privilegiar a prática de disseminação científica como forma de socializar informações científicas a públicos específicos, revestindo-se de uma peculiaridade, pois foi o blog que mais remeteu o leitor a contextos nos quais eram encontradas informações sistematizadas, codificadas e direcionadas a um público específico, ou seja, comunicação científica.

Observou-se no blog Via Gene a prática de endogenia no que diz respeito aos direcionamentos dos inlinks e selflinks (55,23\%). Essa prática, embora preterida no contexto da produção científica tradicional, não depõe contra o propósito do blog, apenas indica uma tendência na forma de composição da postagem a partir de um padrão que se reproduz em razão de mensagens pregressas. A pesquisadora e blogueira o considera um "blog informal cujo conteúdo inclui discussões sobre evolução, genética e biologia molecular".

Para essa pluralidade de comportamentos observados corroboram mecanismos de produção da literatura científica que imbricam práticas tradicionais às formas hipertextuais características da web 2.0. Isso comprova que a ausência de regras pré-definidas, em relação aos blogs, determina, em certa medida, que os mesmos se constituam em espaços adequados para o letramento científico. Essa estratégia pode ser entendida como prática socializante tanto para os agentes pertencentes ao campo quanto para os agentes marginais.

\section{Considerações finais}

As interpretações resultantes da análise dos dados indicam que o uso dos blogs por pesquisadores brasileiros denota comportamentos distintos e pouco conven- 
cionais em relação às intenções identificadas a partir dos links e das postagens nas quais estão incluídos.

Primeiramente, por que um padrão, no que tange à amostra intencional aqui analisada, não pode ser identificado? Ademais, essa hibridez de comportamentos é base constituinte das práticas comunicativas observadas, de tal forma que esses elos textuais podem articular circuitos de compartilhamento de informações relativas à formação cultural, especificamente em relação à Ciência. Essa nova forma de produção da literatura científica e dos mecanismos comunicativos por ela engendrados revela uma atmosfera de alternâncias quanto aos objetos de estudo, às composições discursivas, aos canais adotados e aos públicos atingidos.

Cumpre ressaltar que a delimitação de um público-alvo, que restrinja a audiência a especialistas dominadores de uma linguagem comum ao campo científico, é simplista. Essa afirmativa é de fácil entendimento, pois partirmos da premissa que um autor literário não consegue prever o alcance de seus romances, mesmo inscritos em um suporte físico e previamente categorizados em gêneros do discurso. Essa tarefa é ainda mais árdua para um blogueiro (pesquisador ou não) que conta com o agravante da liquidez do meio/suporte utilizado para a escrita. Esse novo espaço tecnológico movimenta conteúdos fluídos e de abrangência incerta, pois por mais que o tema de interesse seja direcionado a determinada parcela da sociedade, não há categorizações fixas, o que não garante a circulação de informações sobre audiências não previstas pelo produtor. Tais nuances podem ser identificadas através dos links das mensagens. É a partir desses dispositivos que se tem a possibilidade de observar a volatilidade informações que caracteriza os produtos na web 2.0, uma vez que o leitor é remetido a outro conteúdo, outra página, sem ao menos saber o intuito dessa citação em meio eletrônico. Essa surpresa é um determinante de suma importância no estabelecimento de estratégias de letramento científico que envolvam comunidades tanto presenciais quanto virtuais. 


\section{Referências}

ALBAGLI, S. Divulgação científica: informação científica para a cidadania? Ciência da Informação, Brasília, v. 25, n. 3, p. 396-404, set./dez. 1996.

BARDIN, L. Análise de conteúdo. 4. ed. São Paulo: Martins Fontes, 2004.

BUENO, W. C. Jornalismo científico no Brasil: o compromisso de uma prática independente. Tese (Doutorado em Comunicação) - Escola de Comunicação e Artes, Universidade de São Paulo, São Paulo, 1984.

BUENO, W. C. Comunicação científica e divulgação científica: aproximações e rupturas conceituais. Informação e Informação, Londrina, v. 15, n. especial, p. 1-12, 2010.

BOURDIEU, P. O senso prático. Petrópolis, RJ: Vozes, 2011.

CRESWELL, J. W. Projeto de pesquisa: métodos qualitativo, quantitativo e misto. 2. ed. Porto Alegre: Artmed, 2007.

FAYARD, P. La Communication scientifique publique. In: FAYARD, P. (Org.). De la vulgarization à la médiatisation. Lyon: Chronique Sociale, 1988.

FRAGOSO, S; RECUERO, R.; AMARAL, S. Métodos de pesquisa para internet. Porto Alegre: Sulina, 2011.

FRANCHI, E. Pedagogia da alfabetização: da oralidade à escrita. São Paulo: Cortez, 1989.

FREIRE, P. R. N. Educação como prática da liberdade. Rio de Janeiro: Paz e Terra, 1967.

GARVEY, D. W. Communication: the essence of science facilitating information among librarians, scientists, engineers and students. Oxford: Pergamon, 1979.

MERTON, R. K. Sociologia: teoria e estrutura. São Paulo: Mestre Jou, 1970

MAMEDE, M.; ZIMMERMANN, E. Letramento científico e cts na formação de professores para o ensino de física. In: SIMPÓSIO NACIONAL DE ENSINO DE FÍSICA, 16., 2007, São Luís. Anais... São Luís, 2007.

MUELLER, S. P. M.; PASSOS, E. J. L. As questões da comunicação científica e a ciência da informação. In: MUELLER, S. P. M.; PASSOS, E. J. L. (Org.).

Comunicação científica. Brasília: UNB, 2000. p. 13-22 
RHEINGOLD, H. Comunidades virtuais. In: DRUCKER, P. (Org.). A comunidade do futuro: idéias para uma nova comunidade. São Paulo: Futura, 1998. cap. 11 , p. $120-127$

SANTOS, G. L. A telemática a serviço da alfabetização científica e tecnológica de professores de 1o. e 2o. graus dos países membros do Mercosul. Colabor@, Curitiba, v. 1, n. 4, p. 35-44, 2002.

SOUSA, R. S. C. Trilhas de comunicação científica: links de postagens de pesquisadores brasileiros nos blogs de ciência. 2011. Tese (Doutorado em Comunicação e Informação) - Curso de Pós-Graduação em Comunicação e Informação, Universidade Federal do Rio Grande do Sul, Porto Alegre, 2011.

TARGINO, M. G. Comunicação científica: uma revisão de seus elementos básicos. Informação \& Sociedade, João Pessoa, v. 10, n. 2, p. 37-85, 2000.

THELWALL, M. Link analysis: an information science approach. Amsterdam: Elsevier Academic, 2004.

THELWALL, M.; VAUGHAN, I.; BJÖRNEBORN, L. Webometrics. Annual Review of Information Science and Technology, Medford, v. 39, p.81-135, 2005.

THELWALL, M. SocSciBot 4. 2013. Disponível em:

<http://socscibot.wlv.ac.uk/>. Acesso em: 08 set. 2013.

ZIMAN, J. M. Conhecimento público. Belo Horizonte: Itatiaia, 1979. (O Homem e a Ciência, 8).

\title{
Complementary views on scientific literacy and the role of researchers in virtual communities
}

\begin{abstract}
This is a webometric study about the discussion around what audiences should be privileged due to the incidence and impacts of scientific information. The research verifies how and with what intensity these changes in information flow have been occurring in the virtual environment. In order to do so, the study surveys four blogs identified in the Anel de Blogs ABC (Um Longo Argumento, Via gene, Cultura Científica and Neurocientista de Plantão). The study uses the software SocSciBot4 (TWEWALL, 2010) and the method of con-
\end{abstract}


Rodrigo Silva Caxias de Sousa, Leilah Santiago Bufrem, Bruna S. do Nascimento

tent analysis (Bardin, 1977) for the categorization of posts made by the researchers responsible for the blogs between January and December 2012. The results indicate that the possibility of new forms of scientific literacy is effectively implemented in the web and suggest that these changes are to be observed in their use of services and platforms for sharing information.

Keywords: Scientific communication. Webometrics. Scientific literacy. Blogs. Brazilian researchers.

Recebido em 15/09/2015

Aceito em 21/12/2015 
${ }^{1}$ No presente trabalho utilizaram-se as seguintes nomenclaturas em detrimento da repetição de seus sinônimos: divulgação científica, disseminação científica e comunicação científica.

\section{APÊNDICE A -Perfil dos Autores/Pesquisadores}

Quadro 4 - I e vínculos institucionais do(s) pesquisador(es) em 2015

\begin{tabular}{|c|c|c|c|}
\hline Blogs Científicos & Autor(es) & Currículo & $\begin{array}{c}\text { Vínculo Institucio- } \\
\text { nal }\end{array}$ \\
\hline Cultura Científica & $\begin{array}{c}\text { Leandro Russovski Tess- } \\
\text { ler }\end{array}$ & $\begin{array}{l}\text { Bacharel em Física pela Universidade } \\
\text { Federal do Rio Grande do Sul (1982), } \\
\text { mestre em Física pela Universidade Esta- } \\
\text { dual de Campinas (1985) e doutor em } \\
\text { Física pela Tel Aviv University (1989). } \\
\text { Professor do IFGW da Universidade Esta- } \\
\text { dual de Campinas desde 1991. }\end{array}$ & UNICAMP \\
\hline Cultura Científica & Milton Lopes Filho & $\begin{array}{l}\text { Bacharel em Matemática pela Pontifícia } \\
\text { Universidade Católica do Rio de Janeiro, } \\
\text { mestre em Matemática pela Pontifícia } \\
\text { Universidade Católica do Rio de Janeiro e } \\
\text { doutor em Matematica pela University of } \\
\text { California, Berkeley (1990). Professor } \\
\text { titular junto ao Departamento de Matemá- } \\
\text { tica Aplicada da UFRJ. Bolsista de Produ- } \\
\text { tividade em Pesquisa 1B/CNPq. }\end{array}$ & UFRJ \\
\hline $\begin{array}{l}\text { Um Longo Argu- } \\
\text { mento }\end{array}$ & $\begin{array}{c}\text { Charles Morphy Dias dos } \\
\text { Santos }\end{array}$ & $\begin{array}{l}\text { Bacharel em Ciências Biológicas pela } \\
\text { Universidade de São Paulo (2001), mestre } \\
\text { em Ciências pela Universidade de São } \\
\text { Paulo (2003) e doutor em Ciências pela } \\
\text { Universidade de São Paulo (2008). Profes- } \\
\text { sor adjunto do Centro de Ciências Natu- } \\
\text { rais e Humanas da Universidade Federal } \\
\text { do ABC. }\end{array}$ & UFABC \\
\hline Via Gene & Ana Cláudia Lessinger & $\begin{array}{l}\text { Bacharel em Ciências Biológicas pela } \\
\text { Universidade Estadual de Campinas } \\
\text { (1993), mestre em Genética e Evolução } \\
\text { pela Universidade Estadual de Campinas } \\
\text { (1997) e doutora em Genética e Biologia } \\
\text { Molecular pela Universidade Estadual de } \\
\text { Campinas (2001). Professora Adjunta da } \\
\text { Universidade Federal de São Carlos } \\
\text { (UFSCar), campus Sorocaba. }\end{array}$ & UFSCar \\
\hline $\begin{array}{l}\text { Neurocientista de } \\
\text { Plantão }\end{array}$ & $\begin{array}{l}\text { Suzana Herculano- } \\
\text { Houzel }\end{array}$ & $\begin{array}{l}\text { Bacharel em Biologia pela Universidade } \\
\text { Federal do Rio de Janeiro, mestre em } \\
\text { Neurosciences pela Case Western Reserve } \\
\text { University (EUA), doutora em Neurosci- } \\
\text { ences pela Universidade Paris VI (França). } \\
\text { Professora associada da UFRJ. Bolsista de } \\
\text { Produtividade em Pesquisa 1D/CNPq. }\end{array}$ & UFRJ \\
\hline
\end{tabular}


Olhares complementares sobre letramento científico e o papel dos pesquisadores em comunidades

virtuais

Rodrigo Silva Caxias de Sousa, Leilah Santiago Bufrem, Bruna S. do Nascimento 